\title{
JURISDICTION IN BANKRUPTCY
}

\author{
William E. Mussman* and Stefan A. Riesenfeld $\dagger$ \\ I \\ General Features of Jurisdiction in Bankruptcy
}

A. Judicial Jurisdiction in Bankruptcy as Distinguished from
Legislative Jurisdiction

The following study was undertaken for the purpose of describing the judicial business which is imposed upon the lower federal courts in the administration of the Bankruptcy Act of r898, as revised by the Chandler Act of 1938. 1 Our concern here is with the problems centering around judicial as distinguished from legislative jurisdiction, ${ }^{2}$ the latter dealing only with the powers of Congress under the bankruptcy clause of the Constitution. ${ }^{3}$ The history of bankruptcy in the United States ${ }^{*}$ has been summarized by Justice Cardozo as that of "an expanding concept that has had to fight its way." liberalization." While, in the words of the Supreme Court, the subject of bankruptcy is incapable of final definition, ${ }^{7}$ it may be stated generally that it covers the liquidation or rehabilitation of embarrassed estates. ${ }^{8}$ At any rate, this is the scope of bankruptcy under the present act.

\section{B. The Nature of Federal Jurisdiction in Bankruptcy in General}

Federal jurisdiction ${ }^{9}$ in bankruptcy covers the whole business of the federal courts in the administration of the Bankruptcy Act. It encompasses all their activities in connection with "straight" bankruptcy proceedings, ${ }^{10}$ railroad and corporate re-

* Assistant Professor of Law, University of Minnesota.

+ Professor of Law, University of Minnesota.

${ }^{1} 52$ STAT. 883 (1938), II U. S. C. §I ff. (1940). We shall hereafter simply refer to the section numbers of the Act.

${ }^{2}$ For a discussion of the two concepts, see Restatement, Conflict of Laws $\$ \$ 59-73$ (1934).

${ }^{3}$ U. S. Const. Art I, $\$ 8, \mathrm{cl}$. 4 .

"See Chardes Warren, Bankruptcy in United States History (1935); Riesenfeld, The Etolution of Modern Bankruptcy Law, 3 I MiNN. L. Rev. 40I (1947).

${ }^{5}$ Cardozo, J., dissenting in Ashton v. Cameron County Dist., 298 U. S. 513, 535 (1936).

${ }^{\circ}$ See Adair v. Bank of America Ass'n, 303 U. S. 350, 354 (1938).

' See Wright v. Union Central Ins. Co., 304 U. S. 502, 513 (1938).

${ }^{8}$ For a valiant attempt at a functional definition of bankruptcy see Radin, The Nattre of Bankruptcy, 89 U. PA. L. REV. I (I940).

${ }^{2}$ Jurisdiction in this sense relates to the power of the federal courts to properly assume the determination of a case. It is, of course, recognized that "jurisdiction to decide is jurisdiction to make a wrong as well as a right decision" (Pope v. United States, 323 U. S. I, I4 (1944)), and that this power to err applies within certain limits even to the jurisdiction itself. Jurisdiction is unfortunately, as Justice Reed has emphasized, "a word of uncertain meaning" (Driscoll v. Edison Co., 307 U. S. I04, I In (1939)), and "competes with 'right' as one of the most deceptive legal pitfalls." Frankfurter, J., dissenting in Yonkers v. United States, 320 U. S. 685, 695 (1944).

${ }^{10}$ Bankruptcy Act, $\$ \$ I-72$. 
organizations, ${ }^{11}$ arrangements, ${ }^{12}$ and the rehabilitation of farmers, ${ }^{13}$ of wage earners, ${ }^{14}$ and of embarrassed estates belonging to special classes. ${ }^{15}$

While the simplest solution would have been to attribute the jurisdiction to adjudicate all litigations arising in connection with an estate in liquidation or rehabilitation to that federal court in which the main proceeding is pending, this course has not been pursued. As in the whole field of federal jurisdiction, Congress has here been faced with the delicate task of distributing the jurisdiction to decide the various types of litigation which might arise under the Bankruptcy Act between the state and the federal courts-a task which frequently requires a compromise between political expediency and procedural efficiency. ${ }^{16}$ Furthermore, Congress has had to decide not only which of the various federal courts is the most appropriate to take jurisdiction over the principal petition in a particular case ${ }^{17}$ but also whether there should be a further allocation of the total business connected with one main proceeding among the various courts upon territorial principles. Certainly, because of the nationwide scope of the effect of the main proceedings, an attribution of all controversies arising therefrom to the court where they are pending would in some instances impose an undue burden on the parties affected. Two questions immediately arise in this connection: ( $r$ ) What Congress can constitutionally do, and (2) what it has actually done.

The first question can be disposed of briefly. The scope of the bankruptcy clause in conjunction with the judiciary article of the Constitution would have permitted Congress to reserve the entire administration of the Bankruptcy Act to the federal courts $^{18}$ and to extend the territorial jurisdiction of the court in which the main proceeding pends throughout the United States. ${ }^{19}$ But determining the extent to which Congress has exercised this power is a problem of statutory construction requiring separate investigation for each of the various proceedings under the Bankruptcy Act. The solution is beset with doubts and difficulties despite the attempted

${ }^{11} I d ., \$ \$ 77$, Ior-276.

${ }^{22} I d$., $\$ \$ 30 \mathrm{I}-399$.

${ }^{13} I d ., \$ 75$. This section has expired. See note 220 , infra.

${ }^{14} I d$., $\$ \$ 601-686$.

${ }^{20} I d ., \$ \$ 8 \mathrm{r}$ (local taxing agencies), 401-526 (real property arrangements), 701-703 (Maritime Commission liens).

${ }^{10}$ Justice Frankfurter, in his article, Distribution of Judicial Power Between United States and State Cortrts, 13 ConN. L. Q. 499 (1928), concludes that legislation distributing the judicial business to secure a fair balance between state and federal court is particularly subject to the shifting needs of time and circumstance, occasioned primarily by the interplay of industrial and financial forces on social habit and political sentiment.

${ }^{17}$ See Bankruptcy Act, $\$ \$ 2(1), 77(a), 128,322,622$. These provisions apparently concern "venue" rather than "jurisdiction" in the technical sense. On this distinction in general see Industrial Ass'n v. C. I. R., 323 U. S. 310,313 (I945); I Collier, Bankruptcy $\$ 2.13$ ff. (I4th ed., Moore-Mulder, 1940).

${ }_{18}$ Taubel-Scott-Kitzmiller Co. v. Fox, 264 U. S. 426, 430 (1924); Schumacher v. Beeler, 293 U. S. 367,374 (r934); Kalb v. Feuerstein, 308 U. S. 433, 439 (1940).

16 Toland v. Sprague, I2 Pet. 300 (U. S. 1838); United States v. Union Pac. R. R., 98 U. S. 569, 604 (1878); Continental Bank v. Rock Island Ry., 294 U. S. 648, 683 (I935); Mississippi Pub. Corp. v. Murphree, 326 U. S. 438,442 (I946). 
"scientific draftsmanship" of the great revision of $1938 .^{20}$ Jurisdiction in bankruptcy can by no means be characterized as a uniform type of exercise of the judicial power; rather, it is a mixtum compositum consisting of various categories and having several aspects. It is desirable that these aspects and categories be considered before we discuss the jurisdiction connected with the several "proceedings under this Act." "11

\section{General Characterization of Jurisdiction in Bankruptcy}

An analysis of the federal jurisdiction in bankruptcy leads necessarily to the conclusion that it has all the general features of ordinary federal jurisdiction but possesses, at least in part, special characteristics.

\section{Jurisdiction in bankruptcy as limited jurisdiction}

As in all other matters, ${ }^{22}$ the federal courts sitting in bankruptcy, though having very broad and far-reaching powers, are courts of limited jurisdiction. ${ }^{23}$ Their jurisdiction exists only to the extent that it is granted in the Bankruptcy Act and the Federal Judicial Code. One of the most important consequences of this characterization relates to the problem of res judicata, both of adjudications by the federal courts sitting in bankruptcy matters vis-a-vis state courts or federal courts sitting in non-bankruptcy matters or in proceedings under the Act but of a different type, and the adjudications of these courts vis-a-vis the bankruptcy court. No uniform rule applies to these various situations, however, and the answer depends both on the type of question adjudicated and a variety of other factors which will presently appear. $^{24}$

\section{Jurisdiction in bankruptcy as jurisdiction at law or in equity}

The federal jurisdiction in bankruptcy, in the broad sense used here (comprising all proceedings under the Bankruptcy Act as well as all controversies arising out of such proceedings), is either at law or in equity according to the circumstances of the case and the relief prayed. ${ }^{25}$ Although the coalescence of law and equity under the new federal rules $^{20}$ has substantially decreased the significance of the

${ }^{20}$ Although the bankruptcy reform of 1938 was at first hailed as a masterpicce of draftsmanship and scientific lawmaking, the imperfections that are inherent in all human endeavor have become more and more apparent. Compare, for example, McLaughlin, Aspects of the Chandler Bill to Amend the Bankruptcy Act, 4 U. of CuI. L. Rev. 369 (1937), or The Chandler Bankruptcy Amendatory Bill Is Enacted [a symposium], 12 J. N. A. ReF. Baxkr. 124 (1938), with Mulder, Ambigutities in the Chandler Act, 89 U. PA. L. REv. ro (1940).

${ }^{21}$ See notes 9-15, supra.

${ }^{22}$ McCormick v. Sullivant, yo Wheat. 192 (U. S. 1825); Dobie, Ffocral Procedure 25.6 (1928).

${ }^{23}$ Chicot County Dist. v. Baxter Bank, 308 U. S. 37 r, 377 (1940); Duggan v. Sansberry, 327 U. S. 499, 510 (1946). The statement that "The Bankruptey Court is one of general jurisdiction" in Stoll $v$. Gottlieb, 305 U. S. 165,172 n. 14 (1938), is undoubtedly a lapstis linguae of Justice Recd.

${ }^{24}$ See the discussion infra of the following cases: Gratiot State Banls v. Johnson, 249 U. S. 246 (1919); Stoll v. Gottlieb, 305 U. S. 165 (1938); Chicot County Dist. v. Baxter Bank, 308 U. S. 371 (I940); Kalb v. Feuerstein, 308 U. S. 433 (1940); Meyer v. Fleming, 327 U. S. I61 (I946); Heiser v. Woodruff, 327 U. S. 726 (1946); Gardner v. New Jersey, 67 Sup. Ct. 467 (1947); Feiring v. Gano, 114 Colo. 567, I68 Pac. 2d 901 (1946).

${ }^{25} \mathrm{Sec}$ Schoenthal v. Irving Trust Co., 287 U. S. 92, 95 (1932).

${ }^{20} \mathrm{See}$ I Moore's Federal. Practice $\$ \$ 1.02,2.02-2.04$ (1938). 
differentiation in most instances, the characterization of the bankruptcy courts as being primarily courts of equity has had important and extensive legal consequences. It has been an effective instrument in the hands of the Supreme Court in its endeavor to give the federal courts vast powers in the administration of embarrassed estates and to erect upon the rigid foundation of the Bankruptcy Act a superstructure of flexibility and adaptability enabling judicial cure both of defects in draftsmanship of the $\mathrm{Act}^{27}$ and hardships or unfair results flowing from a literal application. ${ }^{28}$

3. Jurisdiction in bankruptcy as being partly in rem, partly quasi in rem and partly in personam

The jurisdiction exercised by the federal court in the administration of the Bankruptcy Act has been characterized in some instances as in rem and in others as quasi in rem, while in still other cases there has never been a doubt that the particular suit by or against the trustee was strictly in personam.

The adjudication in bankruptcy which establishes the status of the debtor as a bankrupt is effective and conclusive erga omnes. ${ }^{29}$ The same holds true in respect to the approval of the petition in reorganization proceedings. ${ }^{30}$ But the "collateral estoppel effect" of these decrees is limited. Thus, the facts upon which the decree is based are not conclusive except as between the parties to the proceeding. ${ }^{31}$ For example, the adjudication based upon a preferential transfer does not establish the preferential nature of the transaction against the transferee..$^{32}$ And this applies to all elements, including the insolvency ${ }^{33}$ However, if a particular creditor, for instance, were to object to the confirmation of an arrangement under Section $366(4)$, he would be bound by the findings of the court on the issues raised before and passed upon by the court. $^{34}$ The adjudication or final approval of the reorganization petition

${ }^{27}$ In Securities \& Exchange Comm'n v. U. S. Realty Co., 3ro U. S. 434 (1940), the court invoked its equity power as a basis for holding that petitioner should have reorganized under Chapter $\mathrm{X}$ instead of Chapter XI in order that a great number of unsecured interests might have adequate protection, although the Act itself was silent on the point.

${ }^{88}$ This "inherent equitable power" has been invoked for this purpose in an ever-increasing variety of situations. Thus, see Pepper v. Litton, 308 U. S. 295 (1939) (disallowance of a claim either as secured or general); American Surety Co. v. Sampsell, 327 U. S. 269 (1946) (subordination of one general claim to another general claim); Heiser v. Woodruff, 327 U. S. 726 (1946) (power to go behind a claim for purposes of investigating for fraud, limited only by principles of res judicata); Vanston Bondholders Protective Com. v. Green, 67 Sup. Ct. 237 (1947) (disallowance of a contractual claim despite its validity under state law).

${ }^{20}$ Michaels v. Post, 21 Wall. 398,428 (U. S. 1874 ); New Lamp Chimney Co. v. Ansonin Brass \& Copper Co., 9r U. S. 656, 66I (1875); Manson v. Williams, 213 U. S. 453, 455 (1909); Gratiot State Bank v. Johnson, 249 U. S. 246,248 (19ro); Meyers v. International Co., 263 U. S. 64,73 (1923).

${ }^{30}$ Bankruptcy Act, §I49; 6 Collier, Bankruptcy 56.13 (I 4th ed., Moore-Oglebay, 1947).

${ }^{31}$ Manson v. Williams, 213 U. S. 453 (1909); Gratiot State Bank v. Johnson, 249 U. S. 246 (1919). In an involuntary petition only the petitioning creditors are parties. While other creditors may intervene, they can appear only in favor of the petition. Bankruptcy Act, $\$ 59(f)$. On the other hand, in reorganization proceedings the creditors may appear against the petition. Bankruptcy Act, \$\$ 337, I 44 .

${ }^{33}$ Gratiot State Bank v. Johnson, 249 U. S. 246 (I919).

${ }^{33}$ Ibid.; Taubel-Scott-Kitzmiller Co. v. Fox, 264 U. S. 426, 429-430 (1924); Liberty Nat. Bank v. Bear, 265 U. S. 365,370 (1924).

${ }^{34} \mathrm{Cf}$. Friend v. Talcott, 228 U. S. 27,41 (1913); Myers v. International Co., 263 U. S. 64 (1923). 
prevents collateral attack in any other court. ${ }^{35}$ Orders of general application by the court, such as those granting discharges and confirming reorganization or arrangement plans, bind all parties to whom the decree purports to apply even though the court assumed jurisdiction over the subject matter erroneously by misconstruing the provisions of the statute ${ }^{36}$ or by failing to appreciate its unconstitutionality. ${ }^{37}$

The jurisdiction of the court attaches from the filing of the petition and extends to all property in the actual or constructive possession of the bankrupt, thereby placing it in custodia legis. The filing of the petition is "a caveat to all the world"38 except in so far as the Bankruptcy Act specifically protects persons dealing with the debtor. ${ }^{39}$

Special consideration must be given to the nature of the jurisdiction of the court in allowing or disallowing claims against the estate. The Supreme Court has recently emphasized that such adjudications are not of actions in personam but of claims against assets only. ${ }^{40}$ This position can conceivably have important consequences with respect to the res judicata effects of such allowance or disallowance. Adjudications of "claims with respect to assets" are commonly called quasi in rem and have not the usual effect of giving rise to an action in debt or estoppel by verdict. ${ }^{41}$ For straight bankruptcy proceedings, it could consequently be argued with plausibility that the allowance or disallowance of a claim by the referee for the reason that he considers it as proved or not proved is not res judicata in a later suit by the creditor against the bankrupt. ${ }^{42}$ It could hardly be contended that privity exists between

st This is expressly provided for by $\$ 149$. The section is construed in Duggan v. Sansberry, 327 U. S. 499 (1946) (holding that the bankruptcy court whose proceedings are stayed under $\$ 113$ may not question even a preliminary ex parte approval).

${ }^{30}$ Stoll v. Gottlieb, 305 U. S. 165 (1938), noted in 23 MiN. L, Rev. 673 (1939).

${ }^{37}$ Chicot County Dist. v. Baxter Bank, 308 U. S. 371 (I940).

${ }^{39}$ Mueller v. Nugent, 184 U. S. I, 14 (1902); May v. Henderson, 268 U. S. íi1, II7 (1925); Gross v. Irving Trust Co., 289 U. S. 342, 344 (1933).

${ }^{30}$ The principal provisions protecting persons dealing with the bankrupt are $\$ \$ 70(\mathrm{~d})$ and $2 \mathrm{r}(\mathrm{g})$. For details see 4 Collier, Bankruptcy $\$ \$ 70.66-.68$ (I4th ed., Moote-Oglebay, 1942) and 2 Collier, BankRUPTCI \$2r.30 (14th ed., Moore-Oglebay, I940).

${ }^{40}$ Meyer v. Fleming, 327 U. S. 16r, r70 (1946); Gardner v. New Jersey, 67 Sup. Ct. 467 (1947). However, Justice Douglas, who wrote the opinions in both of these cases, called the proof and allowance of claims in a receivership case "strictly a proceeding in personam" in Morris v. Jones, 67 Sup. Ct. 451, 455 (1947). These views are hardly consistent.

11 RestateMent, JudGMENTS $\$ \$ 32,76$ (2) (1942).

12 The contrary position is maintained by 3 Collier, BANkruptcr $\$ 57.14$ (14th ed., Moore-Oglebay, 194I) and 2 REMINGTON, BANkRuptcy $\$ 1003$ (4th ed. 1940). However, only a few of the cases cited by the authors in favor of their view have actual holdings to that effect. For examples of those which do so hold, see Elmore-Q. \& Co. v. Henderson-M. Merc. Co., 179 Ala. 548, 60 So. 820 (1913) (allowance held res judicata in later suit against bankrupt, precluding defense of ultra vires); Blanks v. West Point Who. Gro. Co., 225 Ala. 74, $\times 42$ So. 49 (1932) (allowance held res judicata as to existence of claim in later suit); Hargadine-M'Kittrick Co. v. Hudson, 122 Fed. 232 (C. C. A. 8th 1903) (disallowance because of statute of limitations bars later suit in state court); National Surety Co. v. Jean, 36 F. 2 d 468 (C. C. A. 6th 1929) (disallowance held binding on surety of creditor on attachment bond).

It should be observed, however, that the Supreme Court has not committed itself on the question. Lesser v. Gray, 236 U. S. 70 (19I5), which is frequently cited in this connection, held merely that a claim which was disallowed, though erroneously, was discharged if otherwise dischargeable and is therefore no basis for a recovery. Accord with the view in the text, semble, In re McChesney, 58 F.2d $34^{\circ}$ (S. D. Cal. I93I). Even the cases which intimate that a disallowance might be invoked by the bankrupt are careful to point out that the disallowance must be based on the invalidity of the claim and not on other grounds. 
the trustee and the bankrupt in respect to the latter's exempt or post-bankruptcy assets $^{43}$ (although the situation is different in arrangements and reorganizations where the debtor upon termination reacquires his assets). The bankrupt is not a "party" to the proceedings relating to the proof and allowance of claims unless he was actually permitted to object. ${ }^{44}$ It must be noted, of course, that, with the exception of suits against the bankrupt for the sole purpose of charging sureties on bonds given to obtain the release of attached or garnished property or for the purpose of perfecting attachments or garnishments of property not covering the whole amount of the claim, the problem can normally arise only where the creditor sues upon a claim which is either provable but not dischargeable or where the discharge has been withheld. Otherwise the discharge would preclude a recovery, regardless of the allowance or disallowance by the referee. ${ }^{4 J}$ As between the trustee and the creditor the issues which determine the allowance or disallowance should be res judicata, e.g., the preferential character of a transfer. ${ }^{46}$

Of course, actions by the trustee, such as suits for the recovery of preferences, are clearly in personam.

\section{Jurisdiction in bankruptcy as being partly exclusive and paramount and partly con- current}

Jurisdiction in the administration of the Bankruptcy Act is in some aspects concurrent with and in other aspects exclusive of that of the state courts. The general rule is that federal jurisdiction is concurrent unless a specific statute or the Federal Judicial Code has made it exclusive under a power which is within the legislative jurisdiction of Congress. ${ }^{47}$ But even where the jurisdiction over the subject matter is clearly within the concurrent jurisdiction of the federal and state courts, a "rule of comity" has been developed by the Supreme Court to the effect that in proceedings involving the administration of assets which place the assets in custodia legis the jurisdiction of the court which attaches first may not be disturbed-thus making such

${ }^{43} \mathrm{~A}$ judgment in personam obtained by a creditor against the bankrupt before the filing of the petition is, of course, res judicata against the trustee. Heiser v. Woodruff, 327 U. S. 726 (I946). A judgment obtained by a creditor against the bankrupt after the filing of the petition has been considered as not binding on the trustee, I Collier, Bankruptcy $\$$ Ir.09, p. II72 (I4th ed., Moore-Mulder, 1940); however, a judgment rendered after the filing of the petition in a suit begun by the bankrupt before that date concludes the trustee even if he has not intervened. Meyer v. Fleming, 327 U. S. I6r, 166 n. 8 (1946).

14 Whether the bankrupt has a right to object to the allowance of the claim depends on various factors. See 3 Collier, Bankruptcy, $\$ 57.17$ (14th ed., Moore-Oglebay, 1941); 2 Remington, BankRUPTCY $\$ 1025$ (4th ed. 1940). But if the disallowance or allowance were res judicata, there certainly should be such a right in the case of non-dischargeable debts or where the discharge may be withheld.

${ }^{45}$ Lesser v. Gray, 236 U. S. 70 (1915).

${ }^{10}$ Ullman v. Coppard, 246 Fed. 124 (C. C. A. 5th r9r7); Lincoln v. People's Nat'l Bank, 26o Fed. 422 (E. D. Mich. 1919); Metz v. Knobel, 21 F.2d 317 (C. C. A. 2d 1927); Schwartz v. Levine \& Malin, III F.2d 8I (C. C. A. 2d 1940); Feiring v. Gano, II4 Colo. 567, I68 P.2d 9or (I946). Whether the conclusive effect extends to the issue of value is in dispute. See 3 Collier, Bankruptcy $\$ 60.59$ (I4th ed., Moore-Oglebay, 194I). By the same token, a turn-over order against the bankrupt establishes conclusively his duty to surrender which can be enforced in a state court. Sampsell 'v. Gittelman, 55 Cal. App. 2d 208 (1942); Fisher v. Medwedeff, I84 Md. I67, to Atl. 2d 360 (1944).

${ }^{47}$ Dobie, Federal Procedure 39 (1928). 
jurisdiction "exclusive." 88 Interference is deemed to exist, however, only when jurisdiction is exercised directly over the assets and not when mere in personam or otherwise non-conflicting action is taken. ${ }^{49}$ Conversely, the jurisdiction over the assets draws to the court the "exclusive" power to adjudicate all controversies relating to the protection, collection, and distribution of such assets. ${ }^{\text {to }}$ The courts possess the necessary powers to issue all orders and writs protecting their jurisdiction. ${ }^{.1}$

In like manner the federal courts, in the administration of the Bankruptcy Act, acquire upon the filing of the petition either in bankruptcy, reorganization, or arrangement proceedings exclusive jurisdiction over all the property in the actual or constructive possession of the debtor. ${ }^{52}$ This is recognized for straight bankruptcy by the Federal Judicial Code ${ }^{53}$ for reorganization and arrangement by the Bankruptcy Act itself. ${ }^{54}$ The bankruptcy court, like the federal court under general equity principles, has the power to determine all controversies relating to such assets and to protect its jurisdiction by the necessary writs, ${ }^{\text {bi) }}$ the Judicial Code specifically authorizing injunctions against proceedings in state courts..$^{68}$

But the exclusive jurisdiction of the federal courts in the administration of the Bankruptcy Act goes even farther than that based on the comity concept regulating the conflict between courts of otherwise concurrent jurisdiction. Pursuant to its legislative powers under the bankruptcy clause of the Constitution, Congress has, by specific provisions in the Bankruptcy Act which vary for different types of proceedings, authorized the federal courts to deprive the state courts of jurisdiction which they otherwise would have under comity principles. In this respect bank-

${ }^{48}$ Farmers' Loan \& Trust Co. v. Lake St. El. R. R., 177 U. S. 51, 61 (1900); Kline v. Burke Constr. Co., 260 U. S. 226, 23 I (I922); Harkin v. Brundage, 276 U. S. 36, 43 (I928); Pcnn Co. v. Pennsylvania, 294 U. S. 189, I95 (1935); Pennsylvania v. Williams, 294 U. S. 176, 183 (1935); Gordon v. Washington, 295 U. S. 30, 35 (1935); United States v. Klein, 303 U. S. 276, 281 (1938); Princess Lida v. Thompson, 305 U. S. 456, 466 (1939); Toucey v. N. Y. Life Ins. Co., 314 U. S. 118, 135 (1941); Fischer v. American United Ins. Co., 314 U. S. 549, 554 (1942). See Warren, Federal and State Court Interference, 43 Harv. L. REv. 345, 359 (1930).

${ }^{60}$ Riehle v. Margolies, 279 U. S. 218, 223 (r929); Commonwealth Co. v. Bradford, 297 U. S. 613, 6r9 (1936); United States v. Klein, 303 U. S. 276, 281 (1938); Fischer v. American United Ins. Co., 314 U. S. 549,554 (1942).

${ }^{50}$ Farmers' Loan \& 'Trust Co. v. Lake Street El. R.R., I77 U. S. 51, 61 (1900); Richle v. Margolies, 279 U. S. 218, 223 (1929) and cases cited; Princess Lida v. Thompson, 305 U. S. 456, 466 (1939). In receivership cases this jurisdiction over controversies resulting from the "attractive force" of the main proceeding (see Risenfeld, Evolution of Modern Bankruptcy Law, 3 I MinN. L. REv. 401, 410 ff. (1947)) has been called "ancillary jurisdiction." See Wabash R. R. v. Adelburt College, 208 U. S. 38, 54 (Ig08); Barnette v. Wells Fargo Nat'l Bank, 27o U. S. 438, 450-5I (1926).

" Riehle v. Margolies, 279 U. S. 218, 223 (1929). The power exists under $\$_{262}$ of the Federal Judicial Code rather than under $\$ 265$. Julian v. Central Trust Co., I93 U. S. 93, 112 (1904); Toucey v. N. Y. Life Ins. Co., 314 U. S. 118, 134 (1941).

${ }^{82}$ Sce Ex parte Baldwin, 291 U. S. 6ro, 6r5 (1934); Isaacs v. Hobbs Tie \& T. Co., 282 U. S. 734, 737 (193I); Straton v. New, 283 U. S. 318,321 (I93I) and cases cited.

${ }^{s}$ Sec. 256 , REv. STat. $\$ 71$ I (1875), 28 U. S. C. $\$ 371$ (1940).

"Bankruptcy Act, $\$ \$ 111,311$.

${ }^{* 5}$ Bankruptcy Act, $\$ 2(15)$. See Steelman v. All Continent Co., 301 U. S. 278, 289 (I937).

"Federal Judicial Code 5265 , REv. Stat. 5720 (1875), 28 U. S. C. \$379 (1940). See Toucey v. N. Y. Life Ins. Co., 314 U. S. 118, 132 (1941). 
ruptcy jurisdiction is "paramount and exclusive." Th7 Thu, bankruptcy, reorganization, or arrangement proceedings supersede general ${ }^{\mathbf{5 8}}$ state receiverships, ${ }^{59}$ with the limitation that in straight bankruptcy the appointment, if otherwise valid, ${ }^{60}$ must have been made within four months prior to the petition. In certain circumstances the bankruptcy court may stay proceedings in personam pending in other courts. ${ }^{61}$ The paramount character of the bankruptcy jurisdiction expresses itself also in the limited res judicata effect of state adjudications rendered in violation of the bankruptcy jurisdiction, ${ }^{02}$ and in the power of the bankruptcy courts to prevent continuing misapplications of the Bankruptcy Act in state courts. ${ }^{63}$

Where the exclusive jurisdiction of the bankruptcy courts exists, it has been said that no power is given to surrender it to the state courts.".$^{\text {Bu }}$ But it now understood that the bankruptcy court may permit or even require the trial of certain litigation in the state courts or release overencumbered assets. ${ }^{\text {os }}$

In 2 number of cases in which the trustee is a party, the jurisdiction of state courts and federal courts is concurrent either on general principles expressly retained by the Bankruptcy Act or by virtue of specific provisions of the Act to that effect. Thus, for instance, the trustee's suit to recover assets the disposal of which by the debtor amounted to a preferential transfer ${ }^{66}$ or a fraudulent conveyance ${ }^{67}$ can be brought in either the bankruptcy or a state court. Whether in all or some of the instances of concurrent jurisdiction the defendant has a right of removal from a state to the federal court is a question bristling with complicated issues on which there is a scarcity of direct authority. ${ }^{\circ 8}$ (1944).

"Gross v. Irving Trust Co., 289 U. S. 342, 344 (1933); Brown v. Gerdes, 32x U. S. 178, 184

Ex Emil v. Hanley, 318 U. S. 515, 519 (1943).

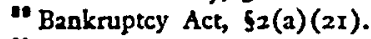

- If the appointment of the receiver or assignee in insolvency was made pursuant to 2 statute which is suspended because of its conflict with the Bankruptey Act, the four-months limitation does not prevent the federal court's assertion of its jurisdiction over the 2ssets. See Emil v. Hanley, 318 U. S. 515, 520 n. 4 (r943); Straton v. New, 283 U. S. 318, 327 (193I). Whether the appointment of a receiver for the purpose of "winding up" an insolvent corporation on the petition of a creditor pursuant to 2 state statute comes within this rule or is excepted by implication of the Bankruptcy Act is 2 difficult question on which state supreme courts and lower federal courts are in conflict. See 25 MrNN. L. Risv. I03 (1940); 30 Mins. L. Rev. 638 (1946).

“See Bankruptey Act, $\$ 5 \mathrm{II}, \mathrm{I} \times 3, \operatorname{II6}(4)$, construed in Foust v. Munson S. S. Lines, 299 U. S. 77 (1936).

" Kalb v. Feuerstein, 308 U. S. 433 (r940).

"Local Loan Co. v. Hunt, 292 U. S. 234 (1934). See Comment, 25 Minv. L. Rev. 790 (194r).

“U. S. Fidelity Co. v. Bray, 225 U. S. 205, 228 (1912); Isaacs v. Hobbs Tie \& T. Co., 282 U. S. 734, 739 (1931). See note 120, infra.

"Ex parse Baldwin, 291 U. S. 6ro, 619 (1933); Thompson v. Magnolia Pet. Co., 309 U. S. 478, 483 (1940); Mangus v. Miller, 317 U. S. 178, 186 (1942); Prudence Corp. v. Ferris, 323 U. S. 650 (1945); Gardner v. New Jersey, 67 Sup. Ct. 467,477 (1947).

"Bankruptcy Act, $\$ 60(\mathrm{~b})$.

"Id., $5567(\mathrm{c}), 70(\mathrm{c})(3)$.

"s Cf. 2 Collier, BANKRUptcy 523.21 (I4th ed., Moore-Oglebay, 1940). At least four types of cases where the trustee is a party to proceedings in 2 state court must be distinguished: ( $I$ ) He may sue in the state court by virtue of \$23(a) and (b) (first clause) as the "universal successor" (See Clark v. Williard, 292 U. S. II2, II4 (1934)) of the bankrupt with respect to the assets enumerated in 570, 
Another important problem which arises, particularly in reorganization proceedings, is the question whether, apart from the exercise of the jurisdiction in rem and the express provisions of the Bankruptcy Act, the federal courts have exclusive or concurrent jurisdiction over controversies relating to the estate. The answer depends largely on the interpretation of Sections 2 and 23 of the Bankruptcy Act and

provided that the cause of action is not within the exclusive jurisdiction of the federal courts apart from bankruptcy; (2) he may sue in the state court on a "non-inherited cause of action" (Herget v. Central Bank Co., 324 U. S. 4, 8 (1945)) vested in him as representative of the creditors by the Bankruptcy Act, $\$ \$ 60$ (preferential transfers), 67 and $70(\mathrm{e})$ (fraudulent convcyances) in conjunction with \$23 (b); (3) he may sue on a cause of action originating in him as a conscquence of his administration, although it is not free from doubt whether such an action is within the exclusive jurisdiction of the bankruptcy court (see infra, Topic D); (4) he may be sued in a state court for acts of his administration pursuant to Rule 66 of the Federal Rules of Civil Procedure (28 U. S. C. following $\$ 723$ (c) (1940)) in connection with $\$ 66$ of the Federal Judicial Code (24 STAr. 554 (1887) as amended, 28 U. S. C. $\$ 125$ (1940)). Cf. McGreavey v. Straw, 90 N. H. 130, 5 A.2d 270 (1939); Robinson v. Trustees, 318 Mass. 121, 60 N. E. 2d 593 (1945); Vass v. Conron Bros. Co., 59 F.2d 969 (C. C. A. 2d 1932).

In these four types of cases concurrent original federal jurisdiction may or may not exist. In respect to Class (I), concurrent federal jurisdiction must be predicated either on the cxistence of a federal question or diversity of citizenship between the bankrttpt and the defendant. The Bankruptey Act in this respect generalizes the principle underlying the celebrated "assignee clause" of $\$ 24$ of the Fcderal Judicial Code. The mere fact that the trustee in bankruptcy is a party does not constitute a federal question in accord with the rule pertaining to federal receivers. Barnette v. Wells Fargo Nevada Nat. Bank, 270 U. S. 438 (1925); Bush v. Elliott, 202 U. S. 477 (1906); Lovell v. Newman, 227 U. S. 412 (I913); Gableman v. Peoria Ry., 179 U. S. 335 (1900). In Class (2) concurrent jurisdiction exists by fiat of the Bankruptcy Act, although a suit based on $\$ 70$ (e) does not necessarily involve a federal question. Whether in Class (3) there is concurrent federal jurisdiction independently of diversity of citizenship or the existence of a federal question depends on the construction of $\$ \$ 2(a)(7)$ and 23 . See infra, Topic D. If diversity of citizenship be required, apparently the trustec's citizenship would be the controlling factor, a result in accord with the rule announced by the courts in respect to quasiassignee receivers (apparently in disregard of the "assignce" clause). Relfe v. Rundle, 103 U. S. 222 (1880); Irvine v. Bankard, 18ז Fed. 206 (C. C. Md. 1910); but cf. Sere "v. Pitot, 6 Cranch 332 (U. S. I810). Finally, in Class (4) federal jurisdiction must be predicated either on diversity of citizenship between the plaintiff and the trustee or on the presence of a federal question.

Removability presupposes generally, of course, that concurrent original federal jurisdiction could have been invoked by the plaintiff. The only exception in this respect which might be important here concerns the removal of certain causes against officers of federal courts under $\$ 33$ of the Judicial Code. However, even in this instance it is thought that the general rule will apply, in as much as the field is narrowly restricted to acts done under specific orders. Cf. Gay v. Ruff, 292 U. S. 25, 31 (I934). As an example of the general rule, it has been held that removability of a suit falling under Class (I) on grounds of diversity requires diversity of citizenship between the bankrupt and the defendant. Whitman v. Chicago \& N. W. Ry., 70 F. Supp. 9 (D. Minn. 1947). However, where the citizenship of the bankrupt controls the original jurisdiction, no additional diversity of citizenship between trustee and defendant should be required for removal purposes; this follows by analogy from the law relating to the "assignee" clause. The removability of actions under Class (2) raises further questions. In the first place, it is not clear whether or not the wording and history of $\$ \$ 23(b), 60,67$ and 70 indicate that the choice of the forum by the trustee should be final, unlike the result under $\$ 23$ (a) and the first clause of $\$ 23(\mathrm{~b})$, which put the trustee in the exact position of the bankrupt. The exclusion of a removal would be in consonance with many express provisions in modern statutes (see the list in Gay v. Ruff, 292 U. S. $25,3^{6}$ n. 17 (1934)) and the construction which the majority of lower federal courts have placed upon $\$ 16$ of the Fair Labor Standards Act (52 STAT., ro68 (1038), 29 U. S. C. $\$ 216$ (1940)). Crouse v. North American Aviation, 68 F. Supp. 934 (W. D. Mo. 1946); Young v. Arbyrd Compress Co., 66 F. Supp. 24I (E. D. Mo. 1946), and cases cited. If this view is not accepted, removability might be based upon the federal nature and regulation of the cause of action involved when the suit is under $\$ 60(\mathrm{~b})$ or $67(\mathrm{e})$. However, in a suit under $\$ 70(\mathrm{e})$ no federal question seems to be involved, and while original federal jurisdiction is given by the Act without diversity, removal would seem to require diversity between the defendant and the erustee (rather than the creditor from whom the trustee derives the right). 
Sections 24 and 256 of the Federal Judicial Code, a question which we discuss below.

\section{Jurisdiction in bankruptcy, summary and plenary}

The jurisdiction which the federal courts exercise in the administration of the Bankruptcy Act is either plenary or summary. The Act itself does not specify when summary jurisdiction is permissible except in a few cases. ${ }^{69}$ In some instances there is reference to cases "where plenary proceedings are necessary." It is now well settled, however, that summary proceedings are permissible in purely administrative matters, and in all controversies over assets either where such assets are in the actual or constructive possession of the bankruptcy court and not held adversely under an ingenuous and substantial claim or where the defendant consents to the summary jurisdiction of the court. ${ }^{71}$ Interestingly, the court has the power to determine by summary proceedings whether the claim of the one in possession is ingenuous and substantial. ${ }^{22}$ The practice in summary proceedings is largely regulated by the General Orders in Bankruptcy ${ }^{73}$ issued under Sections 30 and $75 \mathrm{~b}$ of the Bankruptcy Act, while the practice in plenary proceedings follow the Federal Rules of Civil Procedure. However, even in summary proceedings the Federal Rules are followed in so far as they are not inconsistent with the Act or the General Orders. ${ }^{74}$ The principal difference ${ }^{75}$ consists in the fact that summary jurisdiction is usually exercised in the first instance by the referee rather than the judge, whereas the latter must hear all plenary suits. ${ }^{76}$

\section{Jurisdiction in bankruptcy, territorial or nationwide}

It has been mentioned above that Congress has the power to give the federal district courts nationwide jurisdiction but that it is a question of statutory law whether it has done so in a given case. The Bankruptcy Act has caused considerable confusion in this respect.

According to the wording of the statute, the federal courts which exercise original jurisdiction in bankruptcy 77 are invested with this jurisdiction "within their respective territorial limits."7s With respect to railroad and corporate reorganizations and arrangement proceedings, the Act contains the additional provision that the court

\footnotetext{
${ }^{00}$ Bankruptcy Act, $\$ \$ 67$ (a)(4), 57(1), 70(a)(8). See Taubel-Scott-Kitzmiller Co. v. Fox, 264 U. S. 426, 43 I n. 7 (1924).

${ }^{70}$ Bankruptcy Act, $\$ \$ 60(\mathrm{~b}), 67(\mathrm{e}), 70(\mathrm{c})(3)$.

${ }^{71}$ See Cline v. Kaplan, 323 U. S. 97 (1944) and cases there cited.

${ }^{72}$ Mueller v. Nugent, I84 U. S. I, 15 (1902); May v. Henderson, 268 U. S. III, II6 (1925). It may be noted that Justice Frankfurter has recently made the following comment on this test: "Possession, actual or constructive, is a legal concept full of pitfalls. Even where only private interests are involved the determination of possession, as bankruptcy cases, for instance, abundantly prove, engenders much confusion and conflict." Mexico v. Hoffman, 324 U. S. 30, 40 (1945).

${ }^{73}$ See in U. S. C. A. following $\$ 53$.

"Id., G. O. 37 .

${ }^{70} 2$ Collier, Bankruptcr $\$ 23.02 \mathrm{ff}$. ( $x_{4}$ th ed., Moore-Oglebay, 1940).

${ }^{76}$ Id., \$\$38.02, 38.09; Page v. Arkansas Gas Corp., 286 U. S. 269 (1932).

7 Bankruptcy Act, $\$ \mathrm{I}(\mathrm{ro})$.

${ }^{78} 1 d ., \$ 2(a)$.
} 
possesses jurisdiction over the property of the debtor wherever located, ${ }^{70}$ and it has been held that these words apply to property located outside as well as inside the district of the domiciliary court. ${ }^{80}$ While there is no similar specific provision in the Act governing straight bankruptcy; it is questionable whether the omission produces a substantial difference from the reorganization proceeding. This conclusion is substantiated by the fact that the "wherever located" clause was inserted in the sections on reorganization and arrangements by Congress for the purpose of eliminating the defects existing under the old federal chancery receiver practice. ${ }^{81}$ The Supreme Court has repeatedly stated that since all property of the debtor "wherever located" vests in the trustee upon his appointment, the court of bankruptcy at least thereby acquires exclusive jurisdiction over the assets, even if outside the district, to the extent that they are in the actual or constructive possession of its officer. ${ }^{82}$ But there are decisions by the Court which indicate that even without and before the appointment of the trustee, where the jurisdiction cannot be predicated upon the actual or constructive possession of the court's officer, the assets held by the bankrupt in any district are placed in custodia legis upon the filing of the petition, ${ }^{83}$ and that the primary court of bankruptcy acquires full jurisdiction over such assets at that time. ${ }^{84}$ The Court has held that as a consequence of such jurisdiction the domiciliary court may order and confirm the sale of lands located in another district. ${ }^{85}$

The acquisition of this jurisdiction over the property has been held to entitle the court to protect it against any interference, by judicial proceedings or otherwise, and to extend its process for that purpose outside its territorial limits. To be sure, the Supreme Court has decided this point only for reorganization proceedings. ${ }^{88}$ And it has in two older cases used very strong language to the effect that in straight bankruptcy proceedings the domiciliary court can issue process only within its district and that if protective action be required outside it must be taken by the bankruptcy court in that particular district in ancillary proceedings. ${ }^{87}$ But although the majority of the lower federal courts have relied on these cases, ${ }^{88}$ the Supreme Court has

79Id., $\$ \$ 77$ (a), 11 I, 311. It should be noted that under the wording of $\$ 77$ the jurisdiction over property "wherever located" attaches only after the approval of the petition, while under SSIrI and $3 \mathrm{I}$, in contradistinction to the wording of former $577 \mathrm{~B}$, the filing of the petition controls. The change was made to eliminate the existing confusion. See I Gerdes, Corporate Reorganization 5243 ff. (1936); 2 id., \$852; 6 Collier, Bankruptcy $\$ 3.04$ ( r $_{4}$ th ed., Moore-Oglebay, 1947).

${ }^{10}$ Continental Bank v. Rock Island Ry., 294 U. S. 648, 683 (1935).

"I Gerdes, Corporate Reorganization SI4 (1936); 2 id. 1413 n. 13.

${ }^{82}$ Isaacs r. Hobbs Tie \& T. Co., 282 U. S. 734, 737 (1931); Gross v. Irving Trust Co., 289 U. S. 342, 344 (1933); 2 Gerdes, Corporate Reorganization 1365 ff. (1936).

${ }^{82}$ Acme Harveter Co. v. Beekman Lumber Co., 222 U. S. 300 (1911).

s6 Robertson Y. Howard, 229 U. S. 254, 26r (x913).

ss ybid.

${ }^{*}$ Ex parte Baldwin, 291 U. S. 6ro, 6r5 (1934); Continental Bank v. Rock Island Ry., 294 U. S. $648,683-4$ (1935).

${ }^{87}$ Babbitt v. Dutcher, 216 U. S. I02, II4 (I9ro); Acme Harvester Co. v. Beekman Lumber Co, 222 U. S. 300, 3II (IgII).

"See, for example, Staunton v. Wooden, 179 Fed. 6I (C. C. A. gth r9ro); Guaranty Trust Co. v. David, 49 F.2d 866 (C. C. A. 8th r93I); Noll v. Hodgson, 70 F.2d I9 (C. C. A. 4th 1934); I Collier, Bankruptcy \$2.1I (r4th ed., Moore-Mulder 1940). In Mar-Tex Realization Corp. v. 
recently made statements indicating that there is no difference between straight bankruptcy and reorganization proceedings in this respect and that resort to ancillary courts is proper but not necessary. ${ }^{89}$ Of course, if there is in fact no infringement of the court's jurisdiction there is no cause for nationwide action. ${ }^{80}$ Since the jurisdiction of the reorganization court is more inclusive than that of the bankruptcy court a wider range of protective action may be authorized and necessary, ${ }^{91}$ but otherwise "the exclusive jurisdiction granted the reorganization court . . . is that which bankruptcy courts have customarily possessed."92

Where plenary proceedings are necessary the territorial limits of the court must be observed. This follows directly for straight bankruptcy proceedings from Section 23 (a) with respect to suits which are regulated by this provision; and there are no apparent reasons why the same rule should not apply to suits in the bankruptcy courts under Sections 60,67 , and 70 . In reorganizations under Chapter X, Section 23 is made specifically inapplicable. Nevertheless, the lower federal courts have held that their jurisdiction can be exercised only over persons in the district, ${ }^{93}$ and the Supreme Court has recently referred to this rule without disapproval. ${ }^{94}$

D. The Legislative Technique of Regulating the Jurisdiction in Bankruptcy

$U_{p}$ to this point questions have been left open which depend directly upon the systematic scheme underlying the various provisions in the Bankruptcy Act regulating the jurisdiction of the courts in its administration. This has been done because the subject has recently been dealt with by the Supreme Court ${ }^{95}$ in a decision which overturns long-established views based on former cases and which carries implications which can be appreciated only in the light of the previous discussion.

The case involved an action in the District Court for the Southern District of New York for an accounting and other relief, brought by trustees who had been appointed by the District Court for the Eastern District of Virginia in a reorganization proceeding under Chapter $\mathrm{X}$. The grounds for federal jurisdiction invoked were the provisions in the Judicial Code relating to suits arising under laws of the United States $^{96}$ and to "all matters and proceedings" in bankruptcy. ${ }^{97}$ The district court

\footnotetext{
Wolfson, 145 F.2d 360,362 (C. C. A. 2 d 1944), Judge Clark volunteered the following language in a reorganization case: "Unlike the territorially limited jurisdiction of the bankruptcy court in an ordinary liquidation proceeding, the summary power of a reorganization court is complete throughout the country."

${ }^{\circ}$ Ex parte Baldwin, 291 U. S. 6ro, 615 (1934).

${ }^{\circ}$ See United States v. Tacoma Oriental S. S. Co., 86 F.2d 363,368 (C. C. A. 9th 1936) ("Jurisdiction over a person outside the lower court's jurisdiction is given to the lower court only if such person is in some manner invading, interfering, or disposing of the debtor's res, and then only to the extent of preventing or forestalling the invasion, interference or disposition of such res."). Thus, it is improper for the court to order a person outside the district to execute a deed for the purpose of clearing title to 2n asset of the estate. In re Lansley, 7 F.2d 888 (C. C. A. 2d 1925).

${ }^{21}$ See Continental Bank v. Rock Island Ry., 294 U. S. 648, 676 (1935).

- Meyer v. Fleming, 327 U. S. 16r, 164 (1946).

"In re Standard Gas \& Electric Co., IIg F.2d 658, 664 (C. C. A. 3d 194I).

"Williams v. Austrian, 67 Sup. Ct. I443, I452 n. 46 (I947).

*Williams v. Austrian, 67 Sup. Ct. 1443 (1947).

- Rev. Stᄉt. $\$ 5563,629$ (I875), 28 U. S. C. $\$ 41(1$ ) (1940).

"T Rev. Stat. $\$ 5563,629$ (1875), 28 U. S. C. $\$ 4$ I (19) (1940).
} 
dismissed for want of jurisdiction, ${ }^{98}$ but the Circuit Court of Appeals reversed ${ }^{90}$ and, on certiorari, the Supreme Court affirmed.

The fundamental question involved was the scope of the grant of jurisdiction in Section 2 of the Bankruptcy Act and its relation to Section 23, which, by a specific provision added by the revision of $1938,{ }^{100}$ is made inapplicable to reorganization proceedings under Chapter $X$. Section 2(a) confers upon all bankruptcy courts

... such jurisdiction at law and in equity as will enable them to exercise original jurisdiction in proceedings under this Act ... to ...

(7) Cause the estates of bankrupts to be collected, reduced to money and distributed, and determine controversies in relation thereto, except as herein otherwise provided ...

Section 23 provides:

a. The United States district courts shall have jurisdiction of all controversies at law and in equity, as distinguished from proceedings under this Act, between . . . trustees as such and adverse claimants concerning the property acquired or claimed by the ... trustees, in the same manner and to the same extent as though such proceedings had not been instituted and such controversies had been between the bankrupts and such adverse claimants.

b. Suits by the ... trustee shall be brought or prosecuted only in the courts where the bankrupt might have brought or prosecuted them if proceedings under this Act had not been instituted, unless by consent of the defendant, except as provided in sections 60,67 , and 70 of this Act.

The juxtaposition of these two sections presented the following alternative analyses of their interrelationship: (I) Section 2 grants power to the bankruptcy court to adjudicate all questions involving the administration of the Bankruptcy Act except in so far as this jurisdiction is limited and qualified by Section 23; (2) Section 2 grants only a limited jurisdiction to be exercised in summary proceedings and Section 23 adds the regulation or grant of jurisdiction over plenary suits.

As long as Section 23 was applicable to all "proceedings in bankruptcy," the question was chiefly of theoretical interest, since the scope of plenary jurisdiction, except perhaps in one instance, ${ }^{101}$ was determined by Section 23. But, as pointed out by the court in the Austrian case, ${ }^{102}$ the elimination of Section 23 from proceedings under Chapter $X$ brought the problem to immediate practical significance in

${ }^{98} 67$ F. Supp. 223 (S. D. N. Y. 1946).

${ }^{00} 159$ F.2d 67 (C. C. A. 2d 1947). $\quad{ }^{100}$ Bankruptcy Act, § 102.

101 The only instance in which the question might have arisen before the amendment of 1938 concerned causes of action arising in the person of the trustec. Sce note 68 , supra, under Class (3). It has been argued by Ross, Federal latrisdiction in Suits by Trustees in Bankruptcy, 20 Iowa L. Rev. 565, 582 (1935), that Section 23 did not apply to this type of action because the bankrupt could not have sued upon it, and that jurisdiction was conferred by $\$ 2(a)(7)$. If this view is correct, as suggested by 2 Collier, Bankruptcy $\$ 23.16$, n. 12 and text (I4th ed., Moore-Oglebay, 1940), the further problem immediately arises whether this grant of plenary jurisdiction is exclusive because of $\$ 256(6)$ of the Federal Judicial Code. See infra the text to and following note 107. To the authors the nonapplicability of $\$ 23$ to this type of case seems, however, questionable and not particularly desirable since it might lead to artificial distinctions-e.g., cases of conversion.

${ }^{102}$ Williams v. Austrian, 67 Sup. Ct. 1443, 1449, dissenting opinion 1456, 1458 (1947). 
as much as the mere fact that a cause of action is vested in a trustee in bankruptcy does not make it one "arising under a statute of the United States"103 and at any rate would not dispense with the requirement of the jurisdictional amount. Probably misled by an erroneous reading of a decision rendered under the Bankruptcy Act of $1867,{ }^{10 *}$ the Supreme Court had previously intimated in a number of cases ${ }^{105}$ that the words "controversies ... as distinguished from proceedings in bankruptcy" contained in Section 23(a) indicated that Section 2 granted only summary jurisdiction and that all plenary jurisdiction depended upon Section 23. However, in the present case the court reviewed the history of the two sections and came to the conclusion that Section 2 granted full summary and plenary jurisdiction "except as herein otherwise provided,"106 and that while Section 23 contained such exception for straight bankruptcy and other rehabilitation proceedings no such limitation existed for the reorganization court under Chapter X. Although Justice Frankfurter entered a vigorous dissent, which pointed out that the decision destroyed the desirable distribution of the judicial business under the Bankruptcy Act between the state and federal courts, ${ }^{107}$ it is not for us to presume that the court will reverse its position in the near future. Consequently, some of the implications and problems following from the "new view" should be investigated. Of those which we here notice, a few were posed but not answered by the court.

I. In the first place, will the effect of the majority opinion be that the federal courts have exclusive jurisdiction over all plenary actions by trustees in reorganization under Chapter $X$ ? Although the majority specifically reserved the question, the dissent intimated that this result would have to follow. Section 256 of the Judicial Code vests exclusive jurisdiction in the federal courts "of all matters and proceedings in bankruptcy." 108 This section of the Code was inserted by the revisers of $x 874$ and employed the terms used in Section $x$ of the Bankruptcy Act of $186 \% .^{109}$ But even at that time it was not considered as settled that the provision of the code made the plenary jurisdiction based upon Section I of the 1867 Act exclusive. ${ }^{110}$ Under the Bankruptcy Act of 1898 not many, if any, problems could arise, ${ }^{111}$ since

203 See note 68, supra.

${ }^{104}$ Lathrop v. Drake, 91 U. S. 516 (1875).

${ }^{205}$ See Bardes v. Hawarden Bank, 178 U. S. 524 (1900); Schumacher v. Beeler, 293 U. S. 367 (1934).

${ }^{100}$ The Court was not troubled by the fact that this interpretation construed $\$ 23(\mathrm{a})$ as if it read "as distinguished from other proceedings under this Act."

${ }_{107}$ Justice Frankfurter has consistently warned against any construction increasing the scope of the business of the federal courts. See, e.g., Ex parte Peru, 318 U. S. 578, 602 (1943); Busby v. Electric Utilitics Union, 323 U. S. 72, 77 (1944).

${ }^{208}$ Rev. Stat. \$7II (1875), 28 U. S. C. \$37I ( 1940$)$.

${ }^{100}$ Section I of the Bankruptcy Act of 1867 provided that the ". . . several district courts of the United States be . . . constituted courts of bankruptcy, and they shall have original jurisdiction . . . in all matters and proceedings in bankruptcy." $\mathrm{x}_{4}$ STAT. $517, \$_{1}(\mathrm{x} 867)$.

${ }^{110}$ In Claflin v. Houseman, 93 U. S. 130,133 (1876) the question was specifically reserved. The lower federal and state courts were fairly well divided on the issue. See Clark v. Ewing, 3 Fed. 83 (N. D. Ill. 1880). The argument was apparently not raised in McKenna v. Simpson, 129 U. S. 506 (1888).

${ }^{212}$ See note 101, supra. 
Section 23 and, after 1903 , Sections $60 \mathrm{~b}, 67 \mathrm{e}$ and $70 \mathrm{e}$ made it clear that the plenary jurisdiction of the federal courts under these sections was concurrent. The revision of $193^{8}$ changed the words "bankruptcy proceedings" in Section 2 and "proceedings in bankruptcy" in Section 23 to "proceedings under this act," but no such change was made in the Federal Judicial Code. Even if it should follow ${ }^{112}$ that the change in the reading of the word "proceedings" in the Bankruptcy Act should change the meaning of the word "proceedings" used in the Judicial Code in Sections $4 \mathrm{r}(\mathrm{xg})$ and $25^{6(6)}$, it would not mean that federal jurisdiction over plenary actions under Chapter $\mathrm{X}$ is exclusive unless the additional and unnecessary assumption were made that the Chandler Act, by substituting "under this act" for "in bankruptcy" in Section 2, made the same change by implication in the Judicial Code. The fact that Section -III of the Bankruptcy Act provides specifically that the jurisdiction over the assets is conclusive might also strengthen the argument that the in personam jurisdiction of the reorganization court is concurrent.

2. Assuming the jurisdiction to be concurrent, a suit brought in the state court would of course be removable into the federal court provided that the requisite jurisdictional amount and either appropriate diversity of citizenship between the trustee and defendant or a question based on a federal statute other than the Bankruptcy Act is present. ${ }^{113}$

3. The plenary jurisdiction of the domiciliary court would not be nationwide merely because of the changed reading of the term "proceeding" in Section 2, since the extraterritorial scope of the protective summary jurisdiction does not follow from the term "proceeding" but from Section Irr. 114

4. The decision will probably have some effect on straight bankruptcy proceedings. In the first place, it lends support to the view that jurisdiction over actions which originate in the person of the trustee may be based on Section 2(7) and brought in the federal court as bankruptcy court ${ }^{115}$ without further qualifications unless they are included in the exception of Section $23^{116}$ In the second place, the decision might possibly affect the construction of Section 24. It has been held that appeals from decisions under Sections 60, 67, and 70 in connection with Section $23 \mathrm{~b}$ followed the federal rules and not Section 24 because the words "controversies arising in proceedings in bankruptcy" in Section 24 apply only to controversies adjudicated

${ }^{112} \mathrm{Cf}$. the dissent of Justice Frankfurter in the Austrian case.

${ }^{123}$ See note 68, supra. Of course, if the trustee sues the defendant in a court of the state of which the defendant but not the trustee is a citizen, no removal on the basis of diversity is possible atthough the federal court of that state would have had original jurisdiction since such removal requires that the defendant be a non-resident of the forum. Cf. Dobie, Federal Procedure 365 (1928).

${ }^{124}$ See supre Topic $\mathrm{C}(5)$.

115 Under the terminology of the Bankruptcy Act the federal court sits as a "court of bankruptcy" whenever its jursidiction depends on the Bankruptey Act and is independent of diversity of citizenship or a question arising under a federal law other than the Bankruptcy Act. While the procedure of the federal court sitting as bankruptcy court in plenary actions is identical with that where it sits on other grounds of federal jurisdietion, its substantive powers might vary. Thus, see National Automatic Tool Co. v. Goldie, 27 F. Supp. 399 (D. Minn. 1939).

${ }^{110}$ See note ror, supra. 
under Section 2 of the Act. ${ }^{117}$ Under the new reading of Section 2 it could be argued that the controversies mentioned in the exception clause of Section 23(b) fall within the jurisdiction granted in Section 2 and are therefore appealable under Section $24{ }^{118}$ The recent change of the period for appeal under the Federal Rules to thirty days ${ }^{119}$ will make the question moot except where the judgment involves less than $\$ 500$.

5. The last point to be mentioned is the question whether the non-domiciliary federal court to which the trustee resorts as bankruptcy court can direct the trustee to sue in the state court if the cause of action depends entirely on state law and other grounds for federal jurisdiction are not present. An affirmative answer would be in line with intimations in Supreme Court cases $^{120}$ and would seemingly overcome the chief objections raised by Justice Frankfurter against the results of the Austrian case.

In the light of the doubts here suggested it would seem advisable to clarify the proposed revision of the Federal Judicial Code $^{121}$ so as to take care of the problems.

\section{II}

The Business of the Federal Courts under the Bankruptcy Act

After this consideration of the technical legal aspects of the jurisdiction of federal courts in the administration of the Bankruptcy Act a brief discussion of the major determinations to be made in the various proceedings under the Act seems to be in order.

\section{A. Straight Bankruptcy Proceedings}

"Straight bankruptcy" proceedings ${ }^{122}$ have a two-fold purpose: to convert the assets of the bankrupt into cash for distribution among the creditors, and also to relieve the honest debtor from the weight of oppressive indebtedness and permit him

${ }^{237}$ Lowenstein v. Reikes, 54 F.2d $48 \mathrm{I}$ (C. C. A. 2d 193I); Exchange Nat. Bank v. Meikle, 6r F.2d 176 (C. C. A. 9th 1932); In Matter of Finkelstein, 102 F.2d 688 (C. C. A. 2d 1939); 2 ColliER, BANKRUPTCY \$24.10 (I4th ed., Moore-Oglebay, 1940).

113 It could, however, still be argued that $\$ 24$ does not apply to all adjudications under $\$ 2$ but only to those rendered in summary proceedings, although there is apparently no direct authority to support this view.

111 See the amendment to Rule 73 , to be effective three months after the adjournment of the first regular session of the Eightieth Congress.

${ }^{210} \mathrm{See}$ supra note 65 and text. One writer has recently taken the position that the federal courts cannot abdicate jurisdiction which has been conferred exclusively on them by Congress. Coleman, The Effect of the Presence of a State Law Question on the Exercise of Federal Jurisdiction, 5 Nat. BAR. J. 257, 267 (1947). But might it not be said that the bankruptcy court, in ordering the trustee to sue in the state court, is not abdicating exclusively conferred jurisdiction but is only exercising its supervisory power over the trustee as an officer of the court? This reasoning, of course, would not deprive defendant of his right to remove within the limits pointed out in note 113 .

${ }^{122}$ In its proposed form, $\$ 1334$ provides: "The district courts shall have original jurisdiction, exclusive of the courts of the states, of all matters and proceedings in bankruptcy." See H. R. Doc. No. 7124, 79th Cong., 2d Sess. (1946). This wording will probably increase the difficulties foreseen by Justice Frankfurter.

122 The term "straight bankruptcy" is used by Justice Douglas in Emil v. Hanley, 318 U. S. 515, 517 (1943). 
to start afresh, free from the obligations consequent upon business misfortunes. ${ }^{123}$ The proceedings commence with a petition by the bankrupt ${ }^{124}$ or his creditors. ${ }^{125}$ An involuntary petition must be predicated upon one of the six specifically enumerated and defined acts of bankruptcy. ${ }^{120}$ If the prerequisite conditions are fulfilled the adjudication of the debtor as a bankrupt follows. ${ }^{127}$ Except in non-asset cases begun by voluntary petition, ${ }^{128}$ a trustee is appointed ${ }^{120}$ for the collection of the nonexempt estate and its conversion into cash..$^{130}$ The adjudication of any person except a corporation has the effect of a petition for discharge ${ }^{131}$ which is granted unless the debtor has committed one of a number of specifically listed acts which exclude this privilege. ${ }^{132}$ The discharge prevents the enforcement ${ }^{133}$ of all debts which are provable in bankruptcy and do not belong to certain classes which are exempt from discharge. ${ }^{134}$ Generally the dischargeability of a specific debt is decided by the court in which the enforcement proceeding is pending upon the appropriate plea ${ }^{135}$ and not by the bankruptcy court. In certain circumstances, however, the bankruptcy court might have to decide the question. ${ }^{136}$

${ }^{123}$ Maynard v. Elliott, 283 U. S. 273, 277 ( 1931 ). The purpose of bankruptcy to help the poor but unfortunate debtor through the privilege of discharge is a comparatively recent development. The discharge provisions have been progressively liberalized and the scope of provable and therefore dischargeable debts constantly increased. See Riesenfeld, The Evolution of Modern Bankruptcy Latw, 31 Mins. L. Rev. 401, 406, 407 (1947); 3 Collier, BankRuptcy $\$ 63.03$ (14th ed., Moore-Oglebay, 194r). The discharge is, of course, the incentive for voluntary petitions which greatly outnumber the involuntary petitions. Thus, for the fiscal year ending June 30, 1946, there were about 8,300 voluntary petitions in bankruptcy and 260 involuntary. See Annual Report OF the Director of the Administrative Opfice of the United States Courts 142 (I946).

194 Bankruptcy Act $\$ 59(a)$ in conjunction with $\S_{4}(a)$ (defining persons who may become volunary bankrupts). rupts).

${ }^{125} I d$., $\$ 59(\mathrm{~b})$ in conjunction with $\$ 4(\mathrm{~b})$ (defining the persons who can become involunary bank-

${ }_{125} I d ., \$ 3(a)(1-6)$. The system has been bitterly criticized as medieval and clumsy by Professor Treiman, Acts of Bankruptcy: A Medieval Concepe in Modern Bankrtstcy Law, 52 Harv. L. REv. 189 (1938); but see Riesenfeld, Evolution of Modern Bankruptcy Lau, 31 Miss. L. Rev. 401, 414 (1947). Acts of bankruptcy must be carefully and separately plaaded; defects can be cured only within certain limits. Cf. 2 Coll.1er, Bankruptcy $\$ 18.26$ (14th ed., Moore-Oglebay, 1940); In re De Luxe Oil Co., 36 F. Supp. 287 (D. Minn. 1940).

${ }_{127}^{1 d}$., $\$ 18(\mathrm{~d}),(\mathrm{e}),(f)$ and $(g)$. . ${ }^{138}$ General Order 15.

${ }^{120}$ Bankruptcy Act, $\$ 44$.

${ }^{181} I d ., \$ I_{4}(\mathrm{a})$.

${ }^{130}$ Id., $\$ 47$.

${ }^{139} I d .,{ }_{1} 4(\mathrm{c})(\mathrm{I}-7)$.

138 The precise legal effect of a discharge is the subject of much discussion. To a large extent it is a federal question although beyond that state law becomes operative. See Zavelo v. Reeves, 227 U. S. 625 (1913); Local Loan Co. v. Hunt, 292 U. S. 234 (1934). Thus, state law may permit assignment of a discharged cause of action and consider it as sufficient consideration for a new promisc, Stanck v. White, ry2 Minn. 390, 215 N. W. 784 (1927); Comment, 31 MrN. L. Rev. 391 (1947), or the cntry of a judgment in personam with the execution permanently stayed for the purpose of enforcing the lien under an attachment or garnishment as long as the latter itself is not affected by bankruptcy. Sce Mussman and Riesenfeld, Garnishment and Bankrtiptcy, 27 MiNs. L. REv. 1, 68 ff. (1942).

${ }^{134}$ Bankruptcy Act, $\$ 17$ (a) ( $\left.I-6\right)$.

${ }^{135}$ If the discharge is obtained before judgment, the discharge is pleaded in bar by the defendant bankrupt; if the discharge was obtained after judgment, a petition to stay the enforcement or to enter a satisfaction on the record is made. See Comment, 25 MrNs. L. Rev. 790 (194I).

${ }^{2 s 6}$ The bankruptcy court may except certain debts from the discharge, viz., debts which had been scheduled in a prior proceeding in which a discharge was denied. See Comment, 3 I MinN. L. Rev. $49 \mathrm{I}$ (1947). The bankruptcy court may stay pending suits against the bankrupt on claims which are dischargeable until the question of his discharge is determined. Apparently the permissible and more 
The collection and distribution of assets presents two major phases, viz. the collection of the assets and proof and allowance of claims or adjudication of interventions for reclamation purposes. The bankrupt estate is composed of all nonexempt assets of the bankrupt, ${ }^{137}$ title to which vests in the trustee as of the date of the petition. ${ }^{138}$ But the rights of the trustee go beyond his position as universal successor of the bankrupt. Because of his capacity as representative of the creditors, he may avoid certain transactions which are valid as against the debtor himself. These transactions are "preferential transfers" as defined in the Bankruptcy Act, ${ }^{139}$ judicial liens obtained within four months prior to the filing of the petition while the debtor was insolvent, ${ }^{140}$ fraudulent conveyances as defined by the Bankruptcy Act itself, ${ }^{141}$ and fraudulent or otherwise voidable conveyances under state law. ${ }^{142}$ In order to avail himself of all rights given by state law to creditors, the trustee is also by specific provision of the Act placed in the position of a creditor armed with process. ${ }^{143}$ Liens which are not voidable on one of these grounds survive bankruptcy, although no judicial enforcement proceedings outside of the bankruptcy court may be begun after the petition has been filed. ${ }^{144}$ All assets in the actual or constructive possession of the bankrupt are within the summary jurisdiction of the bankruptcy court, ${ }^{145}$ and title or other interests in them must be asserted in the bankruptcy court through summary reclamation proceedings or by other petitions in the nature of interventions. ${ }^{146}$ The proof and allowance of provable ${ }^{147}$ claims and determination of their priority ${ }^{148}$ follows a fairly informal procedure in the bank-

desirable practice is to petition the court in which the action is pending before resorting to the bankruptcy court. See Connell v. Walker, 29I U. S. I, 5 (I934); I Colnier, Bankruptcy \$rI.08 (I4th ed., MooreMulder 1940). Beyond these cases, the bankruptcy court will intervene only in exceptional instances to vindicate a discharge. See Comment, 25 MrNn. L. Rev. 790 (I94I); Glenn, Effect of Discharge in Bankruptcy: Ancillary Jurisdiction of Federal Court, 30 V.. L. REv. 53 I (I944).

${ }^{237}$ Bankruptcy Act, $\$ \$ 6,70(a)$, construed in Myers v. Matley, 318 U. S. 622 (1943).

${ }^{158}$ Id., $\$ 70(2)$. Suits begun by the bankrupt before the filing of the petition are not terminated because of the filing of the petition, but the trustee has under $\$ 1 I(c)$ the threefold choice of (I) starting a new suit and abating the old one, (2) intervening in the old one, or (3) letting the bankrupt continue although the results conclude the trustee. Meyer v. Fleming, 327 U. S. I61, 165 (1946). Bona fide purchasers from the bankrupt are protected under Sections $21(\mathrm{~g})$ and $70(\mathrm{~d})$.

${ }^{130} I d$., $\$ 60$ in connection with $\$ \mp(30)$.

${ }^{100} \mathrm{Id}$., $\$ 67(\mathrm{a})$. For details see Mussman and Riesenfeld, Garnishment and Bankruptcy, 27 Mavs. L. Rev. I (1942); Fischer v. Pauline Oil Co., 309 U. S. 294 (1940).

111 Id., $\$ 67(\mathrm{~d})$.

${ }^{163} I d$., $\$ 70(\mathrm{c})$ and (e).

${ }^{163} I d$., $\$ 70(c)$. The rights do not depend on the actual existence of a creditor. Where state law attributes to a lien creditor the rights of a bona fide purchaser, the trustee enjoys apparently the same rights regardless of whether chattels or land is involved. See Comment, 25 MiNs. L. REv. 514 (1941). But otherwise the trustee is neither a bona fide purchaser, Glenn, The Chandler Act and the Trustee as a Bona Fide Purchaser, 25 VA. L. Rev. 885 (I939), nor a purchaser at a judicial sale. Myers v. Matley, 318 U. S. 622 (1943).

14t Isaacs v. Hobbs Tie \& T. Co. 282 U. S. 734 (1931). If enforcement has begun, the proceedings whether legal or equitable will not be superseded. Straton y. New, 283 U. S. 3 I8 (193I); Emil v. Hanley, 318 U. S. 515 (1943).

${ }^{265}$ See note $7 \mathrm{I}$, supra, and text.

${ }^{140}$ See 2 Collier, Bankruptcy $\$ \$ 23.1$ I 24.31 (x4th ed., Moore-Oglebay, 1940), id., $\$ 57.07$.

${ }^{247}$ See the catalogue in $\$ 63$, Bankruptcy Act.

248 Bankruptcy Act, $\$ 64$. 
ruptcy court. ${ }^{14 \theta}$ From time to time dividends are declared and distributed. ${ }^{150}$ After all available $\diamond$ assets are collected and their proceeds distributed the proceedings are closed. ${ }^{181}$

\section{B. Railroad Reorganization Proceedings under Section 77}

This section was added to the Act in 1933 to eliminate difficulties which had arisen under the old "umbrella" receiverships, although this paternity has left its marks on the powers and jurisdiction of the court. The present form of the statute is chiefly due to a revision of $1935^{102}$

The proceedings are initiated by either involuntary or voluntary petition which has to be approved by the court. ${ }^{153}$ Upon approval, a trustee is appointed subject to ratification by the Interstate Commerce Commission. ${ }^{154}$ The trustee possesses all the powers of a trustee in bankruptcy, and, if authorized by the judge, of a chancery receiver, ${ }^{155}$ but in contrast to the latter is vested with title. ${ }^{150}$

According to Section $77(1)$ the jurisdiction and powers of the court, the duties of the debtor, and the rights and liabilities of creditors, and of all persons, with respect to the debtor and its property are the same as in straight bankruptcy in so far as such a construction is consistent with other provisions of the section. However, there are a number of important differences from the ordinary bankruptcy proceedings, differences which follow directly from the contrasting purpose of the reorganization proceedings, viz. rehabilitation instead of liquidation. To transform the embarrassed enterprise into a going concern with a sound capital structure, all creditors, secured and unsecured, as well as the stockholders must be brought within the sweep of the plan and the control over the assets must be tightened.

As in straight bankruptcy, the reorganization court obtains exclusive jurisdiction over all the assets of the debtor in its actual or constructive possession, wherever located. Although the statute predicates this jurisdiction upon the approval of the petition $^{167}$ and does not contain an exception relating to property held adversely, it is, now recognized that the date of filing controls and that property held adversely under a claim of title is not under the full sweep of the summary powers. ${ }^{158}$ However, in the details there are significant changes. The proceedings supersede or affect proceedings pending in other courts which straight bankruptcy proceedings would leave untouched. Thus, state and federal receivers "of all or any part of the property

${ }^{180}$ See $i d ., 5565(a)$ and (b), 47(2)(1I). $\quad{ }^{181} I d ., 5547(13)$ and (14), 55(c), 2(a) (8).

16\% Id., 557. The substantive rules determining the provability and allowability of claims are basically principles of federal law and equity. "For nothing decided in Eric Ry. v. Tompkins . . . requircs. a court of bankruptcy, in applying the statutes of the United States governing the liquidation of bankrupt estates, to adopt local rules of law in determining what claims are provable, or to be allowed, or how the bankrupt's estate is to be distributed among claimants." Heiser v. Woodruf, 327 U. S. 726, 732 (1945). See also Vanston Bondholders Prot. Com. v. Green, 67 Sup. Ct. 237 (1946).

${ }^{25 x}$ See 5 Collier, BANkruptcy $\$ \$ 77.01,77.02$ (14th ed., Stephenson-Seligson, 1943).

288 Bankruptcy Act, $\$ 77(\mathrm{a})$.

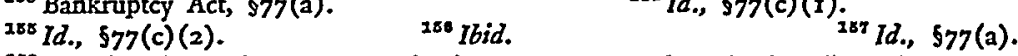

${ }^{158}$ See the dictum in Meyer v. Fleming, 327 U. S. 161,164 (1946). The case is also noteworthy for its holding that the passage of title to the trustee did not abate actions commenced by a stockholder of the debtor in a stockholder's suit. 
of a debtor" appointed under other proceedings are displaced in favor of the reorganization trustee regardless of the time of their appointment. ${ }^{159}$ The reorganization court can stay pending proceedings for the enforcement of a lien ${ }^{160}$ and can even by summary process enjoin the non-judicial enforcement of collateral in the hands of the secured creditors. ${ }^{161}$ The reorganization court has larger powers to stay in personam suits against the debtor than the bankruptcy court. ${ }^{162}$ It may, in the exercise of its sound discretion, stay any suit, whether pending at the time of the petition or not, particularly if the result of the suit would be a burden on the estate. The mere fact that a jury verdict might result in a larger recovery is not a sufficient ground for a stay ${ }^{163}$ although such judgment would apparently be conclusive if filed for proof. ${ }^{164}$ This result is contrary to the rule which seems to be conceded for straight bankruptcy ${ }^{10}$ but in line with that announced by the Supreme Court for the old "umbrella" receiverships ${ }^{166}$ and recently affirmed under the full faith and credit clause for state receiverships, at least for suits commenced prior to the appointment of the receiver. ${ }^{167}$ Since the straight bankruptcy rules for provability and dischargeability do not control in reorganization proceedings, ${ }^{168}$ it is not inconsistent to assume that different principles for the conclusive effect of post-petition judgments against the debtor apply in such proceedings. Furthermore, it should be noted that Section 77 expressly provides that "suits or claims for damages caused by the operation of trains ... may be filed and prosecuted to judgment in any court of competent jurisdiction." ${ }^{169}$ According to its terms, the provision seems to cover suits for prepetition damages which are commenced or prosecuted after the petition and against the debtor, ${ }^{170}$ and it would follow that such judgments are conclusive for proof and allowance. ${ }^{171}$ In the converse situation, where the reorganization court has decided upon the existence and amount of a claim, the result cannot be questioned after the discharge and the return of full control to the debtor. ${ }^{172}$

150 Bankruptcy Act, $\$ 77$ (i). Apparently receivers appointed in foreclosure and cognate suits are not "receivers of any part of the corporate property" within the meaning of this section. Cf. Duparquet $\mathrm{v}$. Evans, 297 U. S. 2i6, 222 (1936).

${ }^{200}$ Id., $577(\mathrm{j})$.

102 Bankruptcy Act, $577(\mathrm{j})$.

${ }^{20 s}$ Foust v. Munson S. S. Lines, 299 U. S. $77^{\circ}$ (1936). A reorganization court under $\$ 77^{B}$ should not enjoin the prosecution of a damage claim against the debtor in a state court if plaintiff needs the judgment for recovery on an insurance policy.

2es This follows from the reasoning of the court in the Munson case which implies that the court felt that the judgment could be presented as conclusive proof for allowance. But contra, as to the conclusive effect of such judgment in proceedings under Chapter $X$, except where the trustee has been made 2 party with the consent of the court, is 6 Collier, Bankruptcy 59.06 (I4th ed., Moore-Oglebay, 1947), and apparently Matter of Paramount Publix Corp., 85 F.2d 42 (C. C. A. 2d 1936).

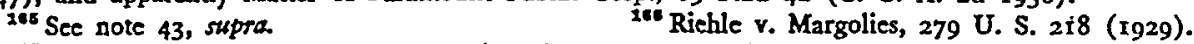

${ }^{207}$ Morris v. Jones, 67 Sup. Ct. 451 (1947). For a critical comment, see Harper, The Supreme Court and the Confitict of Laws, 47 CoL. L. REv. 883, 884f. (1947).

${ }^{108}$ Bankruptcy Act, 577 (b). See 5 Colrier, Bankruptcy 577.20 ( $14^{\text {th }}$ ed., Stephenson-Seligson, 1943).

100 Id., $577(\mathrm{j})$.

${ }^{170}$ See Robinson v. Trustees, 318 Mass. I21, 60 N. E. 2d 593 (1945).

172 In te Chicago \& E. I. Ry., 121 F.2d 785 (C. C. A. 7th 194I).

${ }^{172}$ This result would follow from the discharge provision of $\$ 77(f)$ regardless of the res judicata effect of the decision by the reorganization court. See note 43 , supra, and text. 
Great confusion exists with respect to suits against the trustee. It is now settled that because of Section 66 of the Judicial Code the trustee can be sued without leave from the reorganization court "in respect of any act or transaction of his in carrying on the business" as long as the exclusive in rem jurisdiction of the reorganization court is not interfered with. ${ }^{173}$ It is arguable that additional suability follows apparently from Section $77(\mathfrak{j})$ with respect to damages resulting from the operation of trains regardless of whether or not the cause of action arose prior to the trustee's appointment. ${ }^{174}$ Jurisdiction over such an action against the trustee follows the general principles. Federal jurisdiction, accordingly, depends either on the presence of a separate federal question apart from the pendency of reorganization proceedings and the appointment of the trustee-or on the diversity of citizenship between the trustee and the plaintiff. ${ }^{175}$ The venue is regulated by Section ${ }^{\mathrm{I}}$ of the Judicial Code. It should be noted, however, that this section is satisfied by "the designation by a foreign corporation of an agent for service of process in conformity with the law of the state in which suit is brought against it in one of the federal courts for that state,"176 and that "the effect of Section 66 is to place the trustee operating the road upon the same plane with railroad companies as respects the mode of service."177 Consequently, if the requisite conditions of federal jurisdiction are present the trustee may be sued in any federal court in which the railroad could have been sued through service on the appropriate agent. ${ }^{178}$ State venue statutes are of no effect in this connection. ${ }^{173}$

The most important stage of the proceedings is, of course, the adoption of the reorganization plan. It proceeds in several steps. ${ }^{180}$ The plan as evolved under the guidance of the Interstate Commerce Commission is approved by it and certified to the court. The court hears objections and approves the plan if satisfied that it is equitable and fair and in compliance with other provisions of the statute. The plan is then submitted for a vote to the various materially affected classes of stockholders

${ }^{178}$ Thompson v. Texas Mexican Ry., 66 Sup. Ct. 937 (1946).

${ }^{174}$ See the dicta in In re Chicago \& E. I. Ry., I2I F.2d 785 (C. C. A. 7th 1941). But contra is Robinson v. Trustees, supra note 170 , which holds $\$ 77(j)$ inapplicable to suits against the trustee for pre-reorganization damages.

${ }^{275}$ Section 23 of the Act, even if applicable to railroad reorganizations, would not compel a different result in respect to claims against the trustec of the kind envisaged by $\$ 66$ of the Judicial Cocle or $\$ 77$ (j) of the Bankruptcy Act.

170 Neirbo Co. v. Bethlehem Corp., 308 U. S. 165 (1939).

${ }^{177}$ Eddy v. Lafayette, 163 U. S. 456,464 (1896).

${ }^{278}$ Jacobowitz v. Thomson, I4I F.2d 72 (C. C. A. 2d, 1944). The vicw of Judge Caffey in Dugan v. Gardner, 68 F. Supp. 709 (S. D. N. Y. 1946) that only a resident plaintiff may sue under such circumstances seems to miscontrue the combined effect of the two Supreme Court cases cited in notes 176 and 177 , supra.

${ }^{270}$ Cf. I Moore's Federal Practice \$2.07 (1938). Obviously Chapman v. St. Louis \& S. W. Ry., 7I F. Supp. 1017 (N. D. Tex. 1947), misconceived this rule and also erred in invoking Rule 17 of the Federal Rules of Civil Procedure for suits against receivers. The recent amendment to Rule 17 expressly excludes receivers.

${ }^{180}$ Bankruptcy Act, $\$ 77(\mathrm{e})$. 
and creditors whose claims have been allowed, and, if accepted by the requisite majorities, is confirmed by the court. ${ }^{181}$

\section{Corporate Reorganization under Chapter X}

The functions and jurisdiction of the court in the reorganization of business corporations under Chapter $\mathrm{X}$ are very similar to those in railroad reorganizations. As a consequence, cases decided under Section 77 constitute, within limits, precedents for the reorganization courts under Chapter $X$ and vice versa. ${ }^{182}$ The chief difference concerning jurisdiction is the express provision for the inapplicability of Section 23 , the effect of which has been discussed above. ${ }^{183}$

The proceedings are initiated by a voluntary or involuntary petition ${ }^{184}$ which must be approved by the court ${ }^{185}$ and which vests in the reorganization court exclusive summary jurisdiction over all the debtor's assets which are not held adversely under claim of title. ${ }^{186}$ From the date of the filing the court possesses ample protective powers and may temporarily stay not only prior pending bankruptcy, receivership, or mortgage foreclosure proceedings but also other suits against the debtor if they tend to hamper the administration. ${ }^{187}$ The subsequent approval of the petition automatically stays a prior pending bankruptcy, mortgage foreclosure, or equity receivership proceeding and any act or other proceeding to enforce a lien against the debtor's property. ${ }^{188}$ The reorganization trustee ${ }^{189}$ or debtor in possession ${ }^{190}$ is entitled to obtain possession from such trustee or receiver, including foreclosure receivers, by turnover order if necessary and regardless of the four-months rule applicable in straight bankruptcy. ${ }^{191}$

Suits in personam against the debtor may be commenced ${ }^{202}$ or prosecuted even after the approval of the petition so long as they do not hamper the administration

${ }^{181}$ On the functions of the court in these steps, see R. F. C. v. Denver \& R. G. W. R. R., 66 Sup. Ct. 1282 (1946). On the permissible terms of a plan see also Ecker v. Western Pacific R. R., 318 U. S. 448 (1943); Group of Investors v. Milwaukee R. R., 318 U. S. 523 (1943). For a detailed and illuminating study, see Swaine, $A$ Decade of Railroad Reorganization under Section 77 of the Federal Bankruplcy Act, 56 HaRv. L. REv. 1037, 1193 (1943).

${ }^{282}$ Cf. 6 Collier, BankRuptcr $\$ 0.13$ (I th ed., Moore-Oglebay, 1947).

${ }^{280}$ See the discussion supra under I-D.

196 Bankruptcy Act, $\$ 126 \mathrm{ff}$.

${ }^{188} I d ., 5 \mathrm{r} 4 \mathrm{I} f f$.

${ }^{180}$ Id., SIII. Assets which are held under an undisputed claim of a mere security interest are apparently under the summary jurisdiction of the court. See 6 Collier, BankRUPTCX $\$ \$ 3.05,14.03$ [2].

${ }^{187}$ Id., $\S \mathrm{II}$. For a construction of the portion of this section which relates to bankruptcy, see Duggan v. Sansberry, 327 U. S. 499 (1946). For limitations applying to stays of in personam suits see Foust v. Munson S. S. Lines, 299 U. S. 77 (1936), discussed supra, notes 163 and 164 and text.

188 Bankruptcy Act, \$ri6.

${ }^{280}$ Appointment is mandatory if the liquidated debts exceed $\$ 250,000$. Id., $\$ 156$.

${ }^{100} \mathrm{~A}$ debtor in possession is vested with the rights and subject to the duties of a reorganization trustec. Id., $\$ \mp 88$.

${ }^{101}$ Id., \$257. Cf. Emil v. Hanley, 318 U. S. 515, 522 (1942), recognizing that $\$ 2(2)(21)$ authorizes turnover orders in these cases.

192 The commencement of suits for pre-reorganization claims against the debtor after the appointment of a trustee may raise serious problems as to venue and service in as much as the corporation no longer operates the road. See the discussion on this point in Dugan v. Gardner, 68 F. Supp. 709 (S. D. N. Y. I946). 
or affect title, and the judgments obtained are provable ${ }^{193}$ and apparently conclusive against the estate ${ }^{194}$ and are discharged by the approval of the plan. ${ }^{195}$ The trustee or the debtor in possession may be sued for acts of their administration within the limits of Section 66 of the Judicial Code. ${ }^{196}$ Federal jurisdiction and venue follow the principles discussed above in connection with railroad reorganization. ${ }^{107}$

Approval $^{198}$ and confirmation ${ }^{199}$ of the plan follow a procedure analogous to that in railroad reorganization with the exception that the Securities and Exchange Commission is the administrative agency to be consulted. ${ }^{200}$

\section{Arrangements under Chapter XI}

Arrangement proceedings are the offspring of the old compositions and extensions which have a long and involved history in Anglo-American law. ${ }^{201}$ They are designed to rehabilitate small and middle-sized businesses. ${ }^{202}$ Large corporations with securities held by the public at large are normally not entitled to resort to the summary procedure of this chapter, ${ }^{203}$ which leads only to an extension or scaling-down of unsecured debts. ${ }^{204}$

The procedure is initiated by voluntary petition outside of or during bankruptcy. ${ }^{205}$ Upon the filing of the petition the arrangement court acquires exclusive jurisdiction of the debtor and his property, wherever located, except where inconsistent with the other provisions of the Act. ${ }^{206}$ It has been held that the jurisdiction thus acquired extends to property subject to security interests, although they are not affected by the plan. ${ }^{207}$ In addition it is expressly provided that the court may stay any act or the commencement or continuation of any proceeding to enforce any lien upon the property of the debtor, upon notice and for cause shown. ${ }^{208}$ The court may further enjoin or stay the commencement or continuation of other suits, ${ }^{209}$ which is important if such suit might, for instance, result in the loss by the debtor of his major source of payment. ${ }^{210}$

If the plan effects a mere extension, all existing unsecured claims are provable, ${ }^{211}$ but if a settlement or satisfaction is sought the ordinary bankruptcy rules of provabil-

192 See Bankruptcy Act, $\$ 196$ in conjunction with $\$ 106(4)$.

19* Contra, 6 Collier, Bankruptcy 59.06. But see the discussion supra, notes 163 and 164 and text.

105 Bankruptcy Act, $\$ \$ 224(1), 228(\mathrm{I})$.

100 The debtor in possession has been held to come within the purview of $\$ 66$. See 6 Collizr, BakKRUPTCY, $\$ \$ 3.30[2], 8.16$.

${ }^{101}$ See supra, notes 176-179 and text. $\quad{ }^{198}$ Bankruptcy Act, $55174,216 f$.

${ }^{100} I d ., 5221 \mathrm{ff}$. ${ }^{200} I d ., 5172$.

201 See Riesenfeld, The Evolution of Modern Bankrupecy Law, 31 MinN. L. Rev. 401 (1947).

201 S. E. C. v. U. S. Realty \& Improvement Co., 310 U. S. 434, 450 (1940). For an excellent clinical analysis of arrangements under Chapter XI, see Comment, 5I YAlE L. J. 253 (I942). 208 Ibid.

${ }^{208}$ Id., $55321,322$.

${ }^{204}$ Bankruptcy Act, $\$ 5356,37$ r.

207 Lockhart v. Garden City Bank \& Trust Co., Ir6 F.2d 658 (C. C. A. 2d 1940)

${ }^{208}$ Bankruptcy Act, $\$ 314$ (second clause). $\quad{ }^{209}$ Id., 5314 (first clause).

210 Application of Reich, 146 F.2d 162 (C. C. A. 2d 1944).

211 Bankruptcy Act, $\$ 307$. 
ity apply. ${ }^{212}$ If the plan is accepted by the requisite majority and confirmed by the court, $^{213}$ it is binding upon all creditors ${ }^{214}$ and constitutes a discharge of all dischargeable debts provided for in the arrangement. ${ }^{215}$ The court retains jurisdiction if the arrangement so provides until its provisions are performed. ${ }^{216}$ If the debtor defaults he may be adjudicated a bankrupt or the suspended bankruptcy proceedings continued. ${ }^{217}$ The status in this bankruptcy of claims which have arisen after the confirmation has created grave doubts. ${ }^{218}$

\section{E. Agricultural Compositions and Extensions under Section 75}

The Bankruptcy Act incorporates special provisions for the relief of farmers unable to meet their debts as they mature and desiring to effect a composition or an extension of time. ${ }^{219}$ The applicability of the section was limited for a definite period and the petitions under the section had to be filed prior to March $31,1947 .^{220}$ The proceedings consisted, if necessary, of two stages, viz, the attempt to obtain a workable rehabilitation arrangement, ${ }^{221}$ and, in case of failure, an adjudication as bankrupt with a particular statutory right to rehabilitate himself. ${ }^{222}$ The provisions of the act caused a number of doubts and uncertainties, ${ }^{223}$ but since only a relatively small number of cases are still to be processed ${ }^{224}$ no discussion in this study seems to be in order.

\section{F. Wage Earners' Plans under Chapter XIII'225}

The provisions of this chapter permit an individual who is a "wage earner,"228 whether in bankruptcy ${ }^{227}$ or not, ${ }^{228}$ to file a petition in the appropriate bankruptcy

${ }^{212}$ Id., \$352; see 8 Collier, Bankruptcy 57.05 (14th ed., Stephenson-Seligson, 1941). Because of the fact that bankruptcy rules of proof and allowance apply, it would seem that judgments obtained aganst the debtor after the filing of the petition are not conclusive in the arsangement proceedings.

21: Bankruptcy Act, $\$ 36 \mathrm{r} f$.

${ }^{214}$ Id., $\$ 367$. Note that the definition of creditors in $\$ 307$ applies only to mere extension arrangements.

${ }^{218}$ Id., $537 x$.

217 ld., 5377.

210 Bankruptcy Act, $5 \$ 368,357(7)$.

218 See 8 Colrier, BAnxruptcy $\$ 10.12$ (14th ed., Stephenson-Seligson, 194I); In re Plymack, 5 Ax. B. R. (N.s.) 818 (I94I).

22" Bankruptcy Act, 575. For the definition of a "farmer" for the purposes of this section, see Beritez v. Bank, 313 U. S. 270 (1941).

${ }^{220} I d ., \$ 75(c)$, as amended by Act of June 3, 1946, c. 280,60 STAT. 230 (1946).

${ }^{2 x 2}$ Id. $\$ 75(\mathrm{a}-\mathrm{r})$.

${ }^{223}$ Sec Diamond and Letzler, The New Frazier-Lemke Act, 37 Col. L. Rev. 1092 (I937); 5 Collier, BANKRUPTCY 575.01 ff. (I 4 th ed., Stephenson-Seligon, 1943).

'11 On June $30,1946,1,540$ proceedings were pending, with only $122 \mathrm{new}$ petitions during the fiscal year ending on that date. See Annual Report of the Director of the Administrative Opfice of THE UNited States CouRts 130 (1946). For the proposals of a permanent chapter for farmers, see Note, 56 YALE L. J. 982 (1947).

${ }^{298}$ For a history of the legislation, see Woodbridge, Wage Earners' Plans in the Federal Courts, 26 MINN. L. REv. 775 (1942).

220 A "wage earner" according to $\$ 606(8)$. is "an individual who works for wages, salary or hire at a rate of compensation which, when added to all his other income, does not exceed \$3000 a year."

${ }_{927}$ Bankruptcy Act, $\$ 62 \mathrm{I}$. The bankruptcy proceedings are automatically stayed by the filing of the petition. Id., $\$ 625$.

228 Id., $\$ 622$. 
court stating that he is insolvent and desires to effect either a composition or an extension of time ${ }^{220}$ for the payment of his debts. ${ }^{230}$ The jurisdiction of the court over the debtor, his property wherever located, and his wages or earnings during the period of consummation of the plan attaches as of the date of filing, ${ }^{231}$ and the court is given power to stay the commencement or continuation of in personam suits and on cause shown to enjoin any act or the commencement or continuation of any proceedings to enforce any lien on the debtor's property. ${ }^{232}$ The plan is presented by the debtor and must deal generally with unsecured debts ${ }^{233}$ and may deal severally with secured debts. ${ }^{234}$ Upon appropriate approval by the creditors, ${ }^{235}$ the court must confirm the plan if satisfied in certain specified respects. ${ }^{236}$ Upon acceptance, a trustee is appointed for the purpose of receiving the periodic payment of wages and supervising the execution of the plan. ${ }^{237}$ During the period of extension, the court is given the power necessary to effect the consummation of the plan, ${ }^{238}$ and, upon its completion, the court orders a discharge which is effective as against all claims which would be dischargeable in straight bankruptcy if the creditor did not accept the plan (but regardless of whether he participated).$^{\mathbf{2 3 0}}$

Most of the problems which would seem to arise in this chapter are still without judicial answer. For example, it is provided in Sections 60 and 67 that preferential transfers and certain judicial liens and fraudulent conveyances are void under Chapter XIII proceedings. Apparently the debtor himself can set these aside. ${ }^{240}$ Furthermore, there is no provision for creditors who acquire claims during the extension of the plan, a result which not only tends to defeat the purpose of the act ${ }^{341}$ but also imposes a severe burden of inquiry on prospective creditors. In spite of difficulties, the chapter has received general acclaim. ${ }^{212}$

\footnotetext{
${ }^{200}$ On the distinction between "compositions" and "extensions" for the purpose of determining dischargeability under $\$ 14$ (c)(5), see In re Thompson, 5r F. Supp. 12 (W. D. Va. I943).

${ }^{230}$ Bankruptcy Act, $5 \$ 606(6), 623$. The petition must be made in good faith. Sec Hill v. Topeka Morris Plan Co., 105 F.2d 299 (C. C. A. Ioth 1939).

${ }^{\mathrm{s31} I d ., ~} \$ \$ 6 \mathrm{I} \mathrm{I}, 6 \mathrm{r} 2$.

9sa Id., 56r4.

${ }^{3 s s} I d$, $\$ 646(1)$. Other mandatory provisions are set out in Subsections (4) and (5).

פ34 Id., $\$ 646(2)$.

2ss Id., $\$ \$ 633(3-5), 651,652$.

ss6 Id., $\$ 656(\mathrm{a})$.

${ }^{2 s z} I d ., \$ 633(4)$. The trustee under Chapter XIII is merely a custodian. See Woodbridge, supra note 225 , at 784 .

${ }^{\mathrm{as}} \mathrm{Id}$., $\$ 658$. This power prevents a garnishment or an assignment of wages during this period. See Woodbridge, stspra note 225 , at 792.

${ }^{230}$ Id., $\$ \$ 660,661 ; 9$ CollikR, BANkruptcy $\$ 29.10$ (14th ed., Stephenson-Seligson, 1942).

${ }^{340}$ Cf. 8 Collier, Bankruptcx $\$ 6.32$ (r4th ed., Stephenson-Seligson, 1942); In re Martin Corp., I08 F. 2d I72 (C. C. A. 2d 1939).

${ }^{21}$ See Bundschu, Administration of Wage Earners' Plans in the Bankruptcy Court, 18 J. N. A. REp. Bankr. 55 (1944).

${ }^{343}$ See Woodbridge, supra note 225; Bundschu, supra note 241; Allgood, Wage Earners' Petitions under Chapter XIII, 46 Com. L. I. I7 (I94I); Note, 8 U. of Ckr. L. Rev. Io6 (1940).
} 
III

\section{Conclusion}

The foregoing discussion shows that the Bankruptcy Act supplies a considerable and difficult portion of the work of the federal courts. ${ }^{243}$ The statistical data, although excellent, do not indicate the civil suits which are tried by the federal court as plenary actions, but which either involve the application of the Bankruptcy Act or at least arise out of bankruptcy.

The problem of jurisdiction under the Bankruptcy Act presents intricate and troublesome questions. While a number are intrinsically interwoven with the substantive bankruptcy law, others are occasioned by the fact that the Federal Judicial Code and the Bankruptcy Act have not kept step. The proposed revision of the Judicial Code should clarify the situation and at least prevent unnecessary litigation on jurisdictional points.

${ }^{243}$ For a detailed analysis of all proceedings under the Bankruptcy Act for the fiscal year ending June 30, 1946, see AnNual Report of the Director of the Administrattve Office of the United STATES CoURTs, 128-r89 (1946). The total of petitions filed-ro,196-represents an all-time low. Id. at 70. Of these, I22 were under $\$ 75,54$ under Chapter X, 79 under Chapter XI, I,37I under Chapter XIII and 8,561 under straight bankruptcy. Id., at 130. Of the cases concluded during this fiscal year, totaling $11,788,8,473$ were no-asset cases. $1 d$., at 150 .

For a chronological comparison of the work of the federal courts in bankruptcy, civil, and criminal matters as measured by the cases commenced, compare the graphs, id., at 54, 60, 70 . 